\title{
Effect of Priming on Germination and Vigour Parameters on Kabuli Chickpea (Cicer kabulium L.)
}

\author{
M. Ramesh Chandra*, Prashant Kumar Rai, Rupesh Kumar and Bineeta M. Bara
}

Department of Genetics and Plant Breeding, Naini Agricultural Institute, Sam Higginbottom University of Agriculture, Technology and Sciences, Prayagraj, 211007 U. P., India

*Corresponding author

\section{A B S T R A C T}

\begin{tabular}{|l|}
\hline Ke y w o r d s \\
Chickpea (Kabuli), \\
Priming methods, \\
Characters, \\
Treatments \\
\hline Article Info \\
\hline $\begin{array}{l}\text { Accepted: } \\
\text { 22 July 2019 } \\
\text { Available Online: } \\
\text { 10 August } 2019\end{array}$ \\
\hline
\end{tabular}

The experiment was conducted in Post Graduate Seed Testing Laboratory, Department of Genetics and Plant Breeding, Sam Higginbottom University of Agriculture, Technology and Sciences, Prayagraj (U.P.) during Rabi season 2018, in order to find out the best priming method for chickpea (Kabuli). For different organic and inorganic viz.., $\mathrm{T}_{0}$-Untreated (control), $\mathrm{T}_{1}-\mathrm{DH}_{2} \mathrm{O}-(6 \mathrm{hrs}), \mathrm{T}_{2}$ PEG-5\%(6hrs), $\mathrm{T}_{3}$ - PEG-10\% (6hrs), $\mathrm{T}_{4}$ - PEG-10\% (6hrs), $\mathrm{T}_{5}-\mathrm{NaCl}-5 \%$ (6hrs), $\mathrm{T}_{6}$-NaCl-7\% (6hrs), $\mathrm{T}_{7}-\mathrm{NaCl}-9 \%$ (6hrs), $\mathrm{T}_{8^{-}} \mathrm{CaCl}_{2}-1 \%$ (6hrs), $\mathrm{T}_{9^{-}} \mathrm{CaCl}_{2}-2 \%$ (6hrs), $\mathrm{T}_{10^{-}}$Neem Leaf Extract-5\% (6hrs) and $\mathrm{T}_{11^{-}}$Tulsi Leaf Extract-5\%(6hrs) were taken the seeds were hydrated for their respective time duration and then dried for $6 \mathrm{hrs}$ in shade. It was found that, among all these priming treatments showed significance difference was observed with the control while highest germination percentage, Field emergence, Days to $50 \%$ flowering, Days to $50 \%$ maturity, Number of primary branches, Number of pods per plant, Pod weight(g), Seed yield per plant(g), Biological yield, Harvesting index and seedling character parameters viz.., Germination percentage $(\%)$, Root length $(\mathrm{cm})$, Shoot length $(\mathrm{cm})$, Seedling length $(\mathrm{cm})$, Seedling fresh weight $(\mathrm{gm})$, Seedling dry weight $(\mathrm{gm})$, Vigour index-I, Vigour index -II were observed for seeds treated with PEG15(6hrs) Plant height showed nonsignificant difference with the control. This study helps to improve the seedling character, growth and seed yield with the help of seed priming treatments which are effective, economic, non-toxic and eco-friendly sources.

\section{Introduction}

Pulses are unique crops having in-built mechanism to trap atmospheric nitrogen in their root nodules and restore soil fertility. They are capable of thriving in harsh and fragile environments. Pulses are richest and cheapest source of protein and form major ingredient of diet of vegetarian population of the country. This contains 20 to $25 \%$ proteins as against 8 to $15 \%$ in cereals. Chickpea is rich source of proteins, carbohydrates, minerals and possesses 358 calories which is higher as any of the legume except groundnut and lupine seeds.

Chickpea, a member of Fabaceae, is a selfpollinated true diploid $(2 \mathrm{n}=2 \mathrm{x}=16)$. It is an ancient cool season food legume crop cultivated by man and has been found in Middle Eastern archaeological sites dated 7500-6800 BC (Zohary and Hopf, 2000).

Chickpea is a major and cheap source of protein, predominantly consumed in the form of whole grain or dhal, sprouted grain, green 
or matured dry seeds. It has highly digestible protein $(21.1 \%)$, carbohydrates $(61.5 \%)$ and fats $(4.5 \%)$ and also rich in fiber, minerals and $\beta$-carotene. There are two types of chickpea viz., desi and Kabuli grown in the world. Out of two types of cultivars grown in India, Kabuli type occupies nearly 15 per cent and desi types occupy about 85 per cent of area. Kabuli chickpea is having good market value compared to desi chickpea but requires more specific environmental condition and greater attention to crop management than desi chickpea to produce a quality seed.

The Kabuli chickpea variety is bold seededness, require more soil moisture for emergence, having erect growth habit and grows up to 50 to $60 \mathrm{~cm}$, produces 48 to 55 pods per plant, matures in 95-110 days and moderate resistant to wilt reaction. About 90 per cent of the chickpea is cultivated under rainfed condition hence they frequently experience terminal drought stress resulting in low and unstable yields (Toker et al., 2007)

\section{Kabuli group}

It is the group known as "ram's head". Most of today chickpeas are included within this group. They are varieties mainly grown in Europe, Central and South America. It corresponds to the first chickpea cultivated across the Medit.

The main objective includes to study the effect of different priming treatment on growth and yield attributing traits of chickpea. And to determine the effect of different priming treatment on Seedling characters for Kabuli chickpea. Also to find out the suitable priming treatment for Kabuli chickpea.

\section{Materials and Methods}

The experiment was conducted in post graduate Seed Testing Laboratory,
Department of Genetics and Plant Breeding, Sam Higginbottom University of Agriculture, Technology and Sciences, Prayagraj (U.P.), in order to find out the best priming method for chickpea (Kabuli). 1control and 10 treatments viz.., $\mathrm{T}_{0}$-Untreated (control), $\mathrm{T}_{1}-\mathrm{DH}_{2} \mathrm{O}-(6 \mathrm{hrs})$, $\mathrm{T}_{2^{-}}$PEG-5\%(6hrs), $\mathrm{T}_{3^{-}}$PEG-10\% (6hrs), $\mathrm{T}_{4}-$ PEG-10\% (6hrs), $\mathrm{T}_{5^{-}} \mathrm{NaCl}-5 \%$ (6hrs), $\mathrm{T}_{6^{-}}$ $\mathrm{NaCl}-7 \%$ (6hrs), $\mathrm{T}_{7^{-}} \mathrm{NaCl}-9 \%$ (6hrs), $\mathrm{T}_{8^{-}}$ $\mathrm{CaCl}_{2}-1 \%$ (6hrs), $\mathrm{T}_{9^{-}} \mathrm{CaCl}_{2}-2 \%$ (6hrs), $\mathrm{T}_{10^{-}}$ Neem Leaf Extract-5\% (6hrs) and $\mathrm{T}_{11^{-}}$Tulsi Leaf Extract-5\%(6hrs) are used to find best priming technique for chick pea (Kabuli), seeds were placed on paper towel (Between paper Method for germination percentage.

\section{Yield and yield attributing characteristics}

Plant height $(\mathrm{cm})$, number of pods of ten randomly selected plants $(\mathrm{cm})$ Number of Primary branches, Number of pods per plant, Pod weight $(\mathrm{g})$, Seed yield per plant $(\mathrm{g})$ of each treatment and replication were recorded at maturity. Weight of total quantity of harvested seeds per plot for each treatment and replication was recorded and the yield per hectare was calculated and expressed.

\section{Seed quality parameters}

For seed quality assessment germination test was conducted using the paper towel method as prescribed in ISTA rules (1996), by providing the optimum conditions. The germination counts was made on normal seedlings and expressed in per cent. Vigour indices were computed by adopting the following formula as suggested by Abdul Baki and Anderson (1973) and expressed in number. Vigour Index I = Germination (\%) X Seedling length $(\mathrm{cm})$ Vigour Index II = Germination (\%) X Seedling dry weight (g).

\section{Results and Discussion}

It is evident from the present investigation that 
different types of treatments viz., $\mathrm{DH}_{2} \mathrm{O}, \mathrm{PEG}-$ $5 \%$, PEG-10\%, PEG-15\%, NaCl-5\%, NaCl$7 \%$, NaCl-9\%, $\mathrm{CaCl}_{2}-1 \%, \mathrm{CaCl}_{2}-2 \%$, Neem leaf Extract-5\%, and Tulsi leaf Extract-5\%. Have differential positive effect on the growth attributes such as plant height, number of branches, and number of pods per plant. In general, most of the treatments were found effective in increasing the plant growth at all stages significantly as compared to control. The maximum growth was observed in seeds treated with $\mathrm{T}_{4}$ (PEG-15\%) and minimum recorded in $\mathrm{T}_{0}$ (control).

In the yield parameters there number of pods per plant, biological yield and seed yield per plant were recorded best in treatment $\mathrm{T}_{4}$ (PEG-15\%) and least was seen in $\mathrm{T}_{0}$ (control). For days to maturity the minimum time taken was seen in seeds treated with $\mathrm{T}_{4}$ (PEG-15\%) and maximum was observed in $\mathrm{T}_{0}$ (control).

Table.1 Mean performance of Field Emergence, Days to 50\% maturity, days to 50\% Flowering, Plant height, Pod weight (g), Primary branches, No. of pods per plant, Seed yield per plant, Biological yield, Harvesting index for Kabuli chickpea (Cicer kabulium L.)

\begin{tabular}{|c|c|c|c|c|c|c|c|c|c|c|c|}
\hline $\begin{array}{c}\text { S. } \\
\text { No. }\end{array}$ & $\begin{array}{c}\text { Treatm } \\
\text { ents }\end{array}$ & $\begin{array}{c}\text { Field } \\
\text { Emerge } \\
\text { nce }\end{array}$ & $\begin{array}{l}\text { Plant } \\
\text { height }\end{array}$ & $\begin{array}{c}\text { Days to } \\
50 \% \\
\text { flowering }\end{array}$ & $\begin{array}{c}\text { Days to } \\
\mathbf{5 0 \%} \\
\text { maturity }\end{array}$ & $\begin{array}{c}\text { Primary } \\
\text { branch }\end{array}$ & $\begin{array}{c}\text { Pod } \\
\text { weight }\end{array}$ & $\begin{array}{l}\text { No. } \\
\text { pods } \\
\text { per } \\
\text { plant }\end{array}$ & $\begin{array}{l}\text { Seed } \\
\text { yield } \\
\text { per } \\
\text { plant }\end{array}$ & $\begin{array}{c}\text { Biologi } \\
\text { cal } \\
\text { Yield }\end{array}$ & $\begin{array}{c}\text { Harve } \\
\text { st } \\
\text { Index }\end{array}$ \\
\hline 1 & $\mathrm{~T}_{0}$ & 74.81 & 32.19 & 71.67 & 99.67 & 2.13 & 5.98 & 31.33 & 6.57 & 20.93 & 26.67 \\
\hline 2 & $\mathrm{~T}_{1}$ & 88.15 & 32.97 & 69.00 & 97.00 & 2.87 & 9.99 & 36.87 & 8.33 & 32.98 & 25.28 \\
\hline 3 & $\mathrm{~T}_{2}$ & 85.93 & 32.64 & 69.33 & 97.33 & 2.87 & 9.37 & 34.67 & 8.05 & 32.39 & 24.88 \\
\hline 4 & $\mathrm{~T}_{3}$ & 93.33 & 32.93 & 67.67 & 65.67 & 3.27 & 11.69 & 38.93 & 9.75 & 38.30 & 25.44 \\
\hline 5 & $\mathrm{~T}_{4}$ & 97.04 & 33.92 & 65.00 & 93.00 & 3.73 & 13.32 & 40.40 & 11.63 & 43.72 & 31.42 \\
\hline 6 & $\mathrm{~T}_{5}$ & 94.07 & 34.00 & 66.00 & 94.00 & 3.47 & 12.22 & 40.07 & 10.26 & 38.76 & 30.42 \\
\hline 7 & $\mathrm{~T}_{6}$ & 75.56 & 31.76 & 71.33 & 99.33 & 2.27 & 7.62 & 32.53 & 7.04 & 23.25 & 26.44 \\
\hline 8 & $\mathrm{~T}_{7}$ & 78.52 & 32.39 & 70.67 & 98.67 & 2.53 & 7.77 & 33.47 & 7.20 & 27.45 & 26.35 \\
\hline 9 & $\mathrm{~T}_{8}$ & 80.74 & 32.55 & 70.33 & 98.33 & 2.67 & 8.53 & 35.00 & 7.59 & 29.26 & 24.45 \\
\hline 10 & $\mathrm{~T}_{9}$ & 82.96 & 32.39 & 69.33 & 97.33 & 2.67 & 8.98 & 34.93 & 7.96 & 31.29 & 25.43 \\
\hline 11 & $\mathrm{~T}_{10}$ & 88.89 & 32.33 & 68.67 & 96.67 & 3.00 & 10.76 & 37.33 & 9.06 & 33.57 & 28.05 \\
\hline 12 & $\mathrm{~T}_{11}$ & 91.11 & 32.40 & 68.33 & 96.33 & 3.07 & 11.03 & 38.27 & 9.28 & 34.05 & 28.28 \\
\hline \multicolumn{2}{|c|}{ Grand mean } & 85.93 & 32.70 & 68.94 & 96.94 & 2.88 & 9.77 & 36.15 & 15.80 & 59.38 & 26.93 \\
\hline \multicolumn{2}{|c|}{ SEm \pm} & 0.95 & 0.46 & 0.67 & 0.67 & 0.07 & 0.48 & 0.90 & 0.42 & 0.84 & 1.25 \\
\hline \multicolumn{2}{|r|}{ CD } & 2.80 & 1.36 & 1.97 & 1.97 & 0.21 & 1.40 & 2.64 & 1.22 & 2.48 & 3.65 \\
\hline \multicolumn{2}{|c|}{ CV\% } & 1.92 & 2.40 & 1.69 & 1.20 & 4.35 & 8.47 & 4.31 & 8.40 & 4.55 & 8.00 \\
\hline
\end{tabular}


Table.2 Mean performance of germination (\%), Root length, Shoot length, Seedling length, Seedling fresh weight, Seedling dry weight, Vigour Index I, Vigour Index II of Kabuli chickpea

(Cicer kabulium L.)

\begin{tabular}{|c|c|c|c|c|c|c|c|c|c|}
\hline $\begin{array}{c}\text { S. } \\
\text { NO. }\end{array}$ & Treatments & $\begin{array}{c}\text { Germination } \\
\text { percentage }\end{array}$ & $\begin{array}{c}\text { Root } \\
\text { length(cm) }\end{array}$ & $\begin{array}{c}\text { Shoot } \\
\text { length(cm) }\end{array}$ & $\begin{array}{c}\text { Seedling } \\
\text { length(cm) }\end{array}$ & $\begin{array}{c}\text { Seedling } \\
\text { fresh } \\
\text { weight(g) }\end{array}$ & $\begin{array}{c}\text { Seedling } \\
\text { dry } \\
\text { weight(g) }\end{array}$ & $\begin{array}{c}\text { Vigour } \\
\text { Index I }\end{array}$ & $\begin{array}{c}\text { Vigour } \\
\text { Index II }\end{array}$ \\
\hline $\mathbf{1}$ & $\mathrm{T}_{0}$ & 86.50 & 9.07 & 5.00 & 14.06 & 6.00 & 2.10 & 1216.72 & 181.90 \\
\hline $\mathbf{2}$ & $\mathrm{T}_{1}$ & 87.75 & 15.05 & 8.51 & 23.56 & 7.88 & 3.45 & 2067.72 & 304.33 \\
\hline $\mathbf{3}$ & $\mathrm{T}_{2}$ & 92.50 & 13.69 & 7.13 & 20.83 & 7.03 & 2.65 & 1926.07 & 245.10 \\
\hline $\mathbf{4}$ & $\mathrm{T}_{3}$ & 94.50 & 18.33 & 10.77 & 29.11 & 10.23 & 5.20 & 2751.48 & 489.80 \\
\hline $\mathbf{5}$ & $\mathrm{T}_{4}$ & 95.50 & 22.30 & 13.64 & 35.94 & 12.38 & 6.83 & 3432.75 & 652.80 \\
\hline $\mathbf{6}$ & $\mathrm{T}_{5}$ & 93.00 & 20.31 & 11.70 & 32.00 & 11.60 & 6.23 & 2978.03 & 579.75 \\
\hline $\mathbf{7}$ & $\mathrm{T}_{6}$ & 90.00 & 10.68 & 5.34 & 16.02 & 6.40 & 2.40 & 1440.43 & 214.10 \\
\hline $\mathbf{8}$ & $\mathrm{T}_{7}$ & 87.50 & 11.99 & 6.00 & 17.99 & 6.73 & 2.60 & 1573.59 & 227.28 \\
\hline $\mathbf{9}$ & $\mathrm{T}_{8}$ & 94.00 & 12.12 & 6.24 & 18.36 & 7.00 & 2.83 & 1725.00 & 266.43 \\
\hline $\mathbf{1 0}$ & $\mathrm{T}_{9}$ & 90.50 & 13.13 & 6.79 & 19.92 & 6.88 & 2.58 & 1802.67 & 231.40 \\
\hline $\mathbf{1 1}$ & $\mathrm{T}_{10}$ & 90.25 & 16.70 & 9.13 & 25.82 & 8.55 & 3.95 & 2330.30 & 356.15 \\
\hline $\mathbf{1 2}$ & $\mathrm{T}_{11}$ & 89.75 & 17.37 & 10.06 & 27.42 & 9.65 & 4.90 & 2461.14 & 440.83 \\
\hline \multicolumn{2}{|c|}{$\mathbf{G r a n d ~ m e a n}$} & 90.98 & 15.06 & 8.36 & 23.42 & 8.36 & 3.81 & 2142.16 & 349.15 \\
\hline \multicolumn{2}{r}{$\mathbf{S E D}$} & 2.05 & 0.25 & 0.37 & 0.55 & 0.47 & 0.89 & 77.87 & 82.75 \\
\hline & $\mathbf{C V}$ & 3.18 & 2.39 & 6.18 & 3.30 & 8.31 & 32.95 & 5.14 & 33.52 \\
\hline
\end{tabular}

Seed Quality Parameters

In terms of seed quality parameters the germination \%, root length, shoot length, Seedling Length $(\mathrm{cm})$, Seedling Fresh Weight (g), Seedling Dry Weight (g), Vigor Index I \& Vigor Index II. The treatment $\mathrm{T}_{4}$ (PEG-15\%) recorded a maximum and minimum was shown in $\mathrm{T}_{0}$ (control).

Based on the present investigation it was concluded that the seeds of chickpea were treated with Polyethylene glycol [PEG] $15 \%$ (6hours) $-\mathrm{T}_{4}$ was found suitable in terms of Growth, Seed yield and quality parameters of Chickpea, followed by treatment $T_{5}$ Sodium chloride [ $\mathrm{NaCl}] 1 \%(6 \mathrm{hrs})$ and lowest was observed in treatment $\mathrm{T}_{0}$ (Control) in terms of seed yield.

\section{Acknowledgement}

Authors are thankful to all the members of Department of Genetics and Plant Breeding,
Sam Higginbottom University of Agriculture, Technology and sciences, Prayagraj, (U.P), and India. For providing necessary facilities, encouragement and support.

\section{References}

Amarnath, B.H., Chaurasia, A.K., Arvind, K. (2013) Effect of priming with botanicals and animal waste on germination and seedling vigour in sorghum (Sorghum bicolor L.) seeds. Advances in Applied Science Research, 2015, 6(10): 73-77.

Andoh, H. and kobata, T. (2002) Effect of seed hardening on the seedling emergence and alpha-amylase activity in the grains of wheat and rice sown in dry soil. Japanese journal of Crop science, 71: 220-225.

Bradford, K.J., Steiner, J.J. and Trawatha, S.E. (2002) Seed priming influence on germination and emergence of pepper seed lots. Crop Science, 30: 718-721. 
Conrath, U., Thulke, O., Ketz, V., Schwindling S. and Kohler, A. (2001) Priming as mechanism in induced systemic resistance of plants. European Journal of plant pathology, 107: 113119.

Deepti, P., Swati, N. (2015) Effect of Seed Priming with Some Plant Leaf Extract on Seedling Growth Characteristics and Root Rot Disease in Tomato. International Journal of Agriculture System (IJAS). Vol (4) iss (1).

Ewa, K., and Justyna, P. G. (2003) Effects of matriconditioning on onion seed germination, seedling emergence and associated physical and metabolic events. Plant Growth Regulation, 41(3): 269-278

Fisher, R.A. and Yates, F. (1963) Statistical Table for Biological Agricultural and Medical Research. Oliver and Boyd Publishing Company Private Limited., Edinburgh. 46-63.

Gunasekar, J., Kamaraj, A., Padmavathi, S. (2017) Effect of pre-sowing seed treatment using botanical extract on growth and yield characters in black gram. Plant Archives Vol. 17 No. 2, 1013-1016.

Harris, D., Raghuwanshl, B.S., Gangwar, J.S., Singh, S.C., Joshi, K.D., Rashld, A. and Hollington, P.A., (2001), Participatory evaluation by farmers of on-farm seed priming in wheat in India, Nepal and Pakistan Experimental Agriculture, 37 (3): 403-415.

Kaur, S., Gupta, A. K. and Kaur, N. (2003) Priming of chickpea seeds with water and mannitol overcomes the effect of salt stress on seedling growth. ICPN, 10: $18-19$.

Khan, A., Khalil, S.K., Khan, S.and Afzal, A. (2005) Priming affects crop stand of chickpea. Sarhad Journal of Agriculture. 2005; 21(4): 535-538.

Prashant Kumar Rai, Girjesh Kumar and K.K. Singh (2011) Influence of packaging material and storage time on seed germination and chromosome biology of inbred line of maize (Zea mays L.). Journal of Agricultural Technology 7(6): 1765-1774.

Rashid, A., Harris, D., Hollington, D. A. and Rafiq, M. (2004) Improving the yield of mungbean (Vigna radiate L.) in the North West Frontier Province of Pakistan using on-farm seed priming,. Experimental Agriculture, 40: 233-24

Sen, S., Osborne, DJ. Germination of rye embryos following hydration treatments, enhancement of protein and RNA synthesis and earlier induction of DNA replication. Journal of Experimental Botany. 25(89): 10101019

Toker, C., Lluch, C., Tejera, NA., Serraj, R., Siddique. (2007). Abiotic stress In Chickpea breeding and management. CABI Wallingford, UK, 474-496

Upadhyay, R.G., Sharma, S. and Daramwal, N. S. (1999). Effect of Rhizobium and graded levels of phosphorus on the growth and yield of summer green gram (Phaseolus radiates). Legume Research. 22(4).

\section{How to cite this article:}

Ramesh Chandra M., Prashant Kumar Rai, Rupesh Kumar and Bineeta M. Bara. 2019. Effect of Priming on Germination and Vigour Parameters on Kabuli Chickpea (Cicer kabulium L.). Int.J.Curr.Microbiol.App.Sci. 8(08): 2860-2864. doi: https://doi.org/10.20546/ijcmas.2019.808.329 